\title{
Raja-raja Mataram Kuna dari Sanjaya Sampai Balitung Sebuah Rekonstruksi Berdasarkan Prasasti Wanua Tengah III
}

Kusen

Keywords: inscriptions, history, kings, Ancient Mataram, Sanjaya, Balitung

How to Cite:

Kusen. Raja-raja Mataram Kuna dari Sanjaya Sampai Balitung Sebuah Rekonstruksi Berdasarkan Prasasti Wanua Tengah III. Berkala Arkeologi, 14(2), 82-94.

https://doi.org/10.30883/jba.v14i2.721

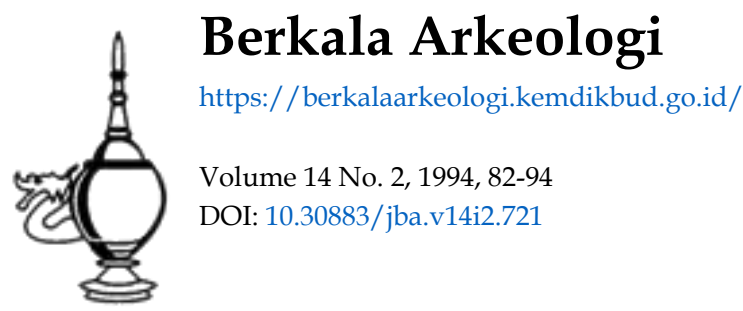

\section{(c) (†) (2)}

This work is licensed under a Creative Commons Attribution-NonCommercial-ShareAlike 4.0 International License. 


\title{
RAJA-RAJA MATARAM KUNA DARI SANJJAYA SAMPAI BALITUNG SEBUAH REKONSTRUKSI BERDASARKAN PRASASTI WANUA TENGAH III
}

\author{
Kus en \\ (Jurusan Arkeologi FS - UGM)
}

\begin{abstract}
Every new archaeological discovery could concievably give rise to historiographical changes And it is quite possible that eventually the whole of the period of ancient history will have to be rewritten in the light of such new discoveries... "(Soekmono, 1965 46)
\end{abstract}

\section{Masalah}

Penulısan sejarah kuna serıngkali lebih banyak menyajikan pertanyaan dan dugaan-dugaan daripada kenyataan. Hal ini terjadi karena sumber sejarah yang ditemukan sangat terbatas dan informasinya tidak selengkap yang diharapkan Oleh sebab itu setiap penemuan data baru akan disambut dengan gembira karena mungkin berguna bagı penyempurnaan rekonstruksi sejarah yang sudah ada. Sehubungan dengan hal ini, pernyataan Soekmono seperti tertera di atas sungguh merupakan arahan yang perlu diperha. tikan oleh mereka yang menekuni bidang sejarah kuna Namun agaknya arahan tersebut terlupakan oleh tim redaksi penulisan SeJarah $\mathrm{Na}$ sional Indonesia li, khususnya yang membahas tentang sejarah raja-raja Mataram Kuna. Hal in tampak jelas dari kenyataan bahwa sampai penerbitan Edisı ke-4, tahun 1992, Sejarah Nasional Indonesıa II sama sekali tidak menyinggung data penting yang termuat dalam prasasti Wanua Tengah ill yang sebenarnya telah ditemukan tahun 1983. Lebih mengherankan lagi bahwa prasastı ını paling tidak sudah dibahas dan disajikan dalam Seminar Sejarah Nasional IV tahun 1985 oleh Djoko Dwiyanto dan Hasan Djafar serta dalam Pertemuan IImiah Arkeologı IV tahun 1986 oleh Djoko Dwiyanto. Mengapa hal inı dapat terjadı?

Makalah ini akan menyajikan kembali data sejarah yang termuat dalam prasasti Wanua Tengah III, khususnya yang berkenaan dengan raja-raja Mataram Kuna yang selama inı terabaikan oleh tim redaksi penulisan Sejarah Nasional Indonesia II. Kemudian akan disajikan rekonstruksı sejarah raja-raja khususnya mulas dari Sañjaya sampai Balitung untuk menunjukkan betapa tingginya nilai sejarah yang terkandung dalam prasasti Wanua Tengah III ini. Akhirnya isi makalah diharapkan dapat menjadi salah satu bahan pertimbangan dalam upaya penulisan kembali sejarah raja-raja Mataram Kuna di masa mendatang.

\section{Prasasti Wanua Tengah III, 830 C (908 M)}

Prasasti Wanua Tengah III, ditemukan oleh seorang penduduk dusun Dungio, desa Gandulan, kecamatan Kaloran, kabupaten Temang gung, Jawa Tengah, pada sekitar bulan Novem. ber 1983. Prasasti terdiri atas dua lempeng tembaga, berhuruf dan berbahasa Jawa Kuna dengan sisipan bahasa Sanskreta dan berangka tahun 830 Ç. Sekarang prasasti tersebut disımpan di Suaka Peninggalan Sejarah dan Purbakala Jawa Tengah di Prambanan (Kusen, 1984)

Alihaksara prasastı pertamakali dilakukan oleh penulis dan kemudian oleh Boechari SeIaın mengalihaksarakan prasasti, Boecharı memberi nama prasasti ini Wanua Tengah III Sejak ditemukan sudah ada beberapa orang yang memanfaatkan atau menyınggung isi prasastı inı dalam tulisan mereka. Di antaranya penulis sendiri (Kusen,1984;1986; 1988; 1989), Boechari (1986; Djoko Owiyanto (1985; 1986) dan Hasan Djafar (1985)

Prasasti Wanua Tengah III pada pokoknya berisı keputusan raja Balitung yang menetapkan sebidang sawah di Wanua Tengah sebagaı sıma bihara di Pikatan. Untuk melatarbelakangi keputusannya, terlebih dahulu diuraikan riwayat sawah sejak pemerıntahan Rake Panangkaran tahun 746 M sampai dikeluarkannya prasasti oleh Balitung di tahun $908 \mathrm{M}$. Adapun ringkasan is prasasti dapat diuraikan dalam butir-butir sebaga berikut:

01. Prasasti dibuka dengan keterangan tentang seorang bernama Rahyangta i Hara adik Rahyangta ri Mdang yang telah mendirikan bihara di Pikatan

02. Rake Panangkaran nalk tahta tangga| 27 November 746. Dia menganugerahkan sebı. dang sawah di Wanua Tengah sebagal sima bihara di Pikatan beserta benih padinya

03. Rake Pararaban naik tahta tanggal 1 Apri! 784. Dia tidak merubah status sawah.

04. Rake Warak Dyah Manara naik tahta tangga 28 Maret 803. Raja ini telah mencabut status sima sawah di Wanua Tengah 
sehıngga tıdak lagı menjadı hak bihara dı Pikatan Rake Warak meninggal dan mendapat sebutan sang lumäh i keläsa.

05. Dyah Gula naik tahta tanggal 5 Agustus 827 Dia tıdak merubah status sawah.

06. Rake Garung anak sang Iumäh i tük naik tahta tanggal 24 Januari 828. Pada tahun 829. dia mengembalikan sawah tersebut kepada bihara di Pikatan. Dalam prasasti Wanua Tengah III terdapat kutipan prasasti Rake Garung yang berkenaan dengan pemulihan status sawah sima yang dahulu dicabut oleh Sri mahãrãja sang lumäh Kelāsa. Kutipan inı tertulis dalam dua versi yaitu dalam bahasa Jawa Kuna dan bahasa Sanskreta Rake Garung meninggal dunia

OT Rake Pikatan Dyah Saladu naik tahta tanggal 22 Februari 847. Raja ini mencabut status sıma sawah di Wanua Tengah Rake Pikatan menınggal dunıa.

O8 Rake Kayuwangi Dyah Lokapäla naik tahta tanggal 27 Mei 855. Dia tidak merubah status sawah. Rake Kayuwangi menınggal aunia

09. Dyah Tagwas naik tahta tanggal 5 Februarı 885 Dia tıdak merubah status sawah. Dia digulingkan darı tahta

10. Rake Panumwangan Dyah Dewendra nakk tahta tanggal 27 September 887. Raja ini tıaak merubah status sawah. Rake Panumwangan digulingkan darı tahta

11 Rake Gurunwangi Dyah Bhadra naik tahta tanggal 27 Januari 887 Dikatakan dalam prasasti bahwa dia lari meninggalkan Istana (minggat) pada tanggal 24 Februarı 887 , sehıngga tahta kerajaan kosong

12 Rake Wungkalhumalang Dyah Jbang nalk tanggal 27 November 894. Dia tıdak merubah status sawah di Wanua Tengah. Rake Wungkalhumalang meninggal dunia

13 Rake Watukura Dyah Ballitung naik tahta tanggal 23 Mei 898 . Mahamantrinya adalah Rakryan i Mino Sri Daksottama Pada tahun 904. Balitung memerintahkan agar semua bıhara dı Jawa dijadikan swatantra Pada tanggal 1 Oktober 908, Balitung bersamasama dengan mahamantrinya memberikan sawah di Wanua Tengah sebagas sima bihara di Pikatan.

14 Selanjutnya dalam prasastı disebutkan nama-nama pejabat yang terlibat dalam upacara penetapan sima, besarnya pagehpageh yang harus dikeluarkan oleh pihak bihara seita ditutup dengan kutukan bagi sıapa saja yang beranı merubah keputusan yang sudah ditetapkan

Demıkianiah rıngkasan Isı prasastı Wanua Tengah III. Dan sebagai catatan perlu dikemukakan bahwa konversı unsur-unsur penanggalan
Saka ke dalam hitungan penanggalan Masehı telah dilakukan oleh Djoko Dwiyanto (1985)

Uraian dalam prasasti yang mencakup kurun waktu yang cukup panjang dan daftar rajaraja yang dilengkapı dengan perincian tanggal hari, pasaran, bulan dan tahun kenaıkkan tahtanya masing-masing justru menımbulkan kesangsian akan keaslian dan kebenaran informas! yang termuat di dalamnya Oleh karena itu sebelum digunakan sebagaı data rekonstruksı sejarah perlu diuji dahulu keaslian dan kebenaran informasi yang termuat di dalamnya Untuk pengujian, isi prasasti Wanua Tengah ill akan dibandingkan dengan isi prasasti-prasasti lain yang sejaman

Dibandingkan dengan isi prasastı laın, hal yang pertamakali menarik perhatian adaiah perbedaan daftar raja-raja Mataram Kuna yang termuat dalam prasasti ini dengan yang termuat dalam prasastı Mantyasih 907 M karena keduanya dikeluarkan oleh Balitung pada tahun yang berturutan (lihat lampıran 1). Mengapa hal ini dapat terjadi? Pertanyaan penting int akan dijawab setelah rekonstruksı sejarah raja-raja Mataram Kuna sejak Sañjaya sampa Balıtung dilakukan

Untuk mengawalı pengujian tentang kebenaran informasi yang termuat dalam prasastı Wanua Tengah, berikut ını akan dilıhat apakah nama-nama yang disebut dalam prasastı ını juga ditemukan dalam prasastı lain. Hasil perbandıngan yang telah dilakukan adalah sebagaı berikut

01. Nama Rahyangta / Hara, adık Rahyangta "I Mdang sebagai pendiri bihara di Pikatan tidak ditemukan dalam prasastı lain

02. Rake Panangkaran yang nalk tahta tanun $746 \mathrm{M}$, selain disebut dalam prasastı Mantyasih 907 M, juga disebut dalam prasas: Kalasan $778 \mathrm{M}$ dan prasastı Abhayagırıw:hara $792 \mathrm{M}$

03. Rake Panaraban yang naık tahta tahun 784 $M$ tidak disebut dalam prasastı laın. Namun demikian di dekat gapura pertama kompleks Ratu Boko telah ditemukan sebuah lempengan emas bertulisan om ta kı hum jah swahä panarabwan hanıpas (Suhamir, 1950:36)

04. Nama Rake Warak yang naik tahta tahun 803 M juga ditemukan dalam prasast Mantyasih $907 \mathrm{M}$

05. Nama Dyah Gula yang nalk tahta tahun 827 $M$ tidak dijumpai dalam prasastı lain

06. Rake Garung yang naik tahta tahun 828 M selaın juga disebut dalam prasasts Mantyasır. 907 M, disebut pula dalam prasastı Garung 819 M. Dalam prasast tahun 819 M dia menyebut dirinya Rakarayan । Garung tanpa gelar maharaja 
07. Nama Rake Pikalan Dyah Saladu yang naik tahta tahun 847 M secara lengkap tidak ditemukan dalam prasasti lain. Namun gelar Rake Pikatan ditemukan dalam prasasti Mantyasih, tulisan singkat di candi Plaosan lor dan prasasti Wanua Tengah I $863 \mathrm{M}$. Dalam prasastı yang disebut terakhir nama dirı Rake PIkatan adalah Pu Manuku. Selanjutnya, nama Dyah Salad u ditemukan dalam tuiısan sıngkat di candi Plaosan Lor namun dengan gelar Rake Gurunwangi.

08. Nama Rake Kayuwangi yang nalk tahta tahun $855 \mathrm{M}$ selaın disebut dalam prasasti Mantyasıh, juga disebut dalam prasasti Siwagr ha $856 M$, prasasti Wanua Tengah I $863 \mathrm{M}$, dan prasasti Kwak / 879 M.

09 Nama Dyah Tagwas yang naik tahta tahun 885 M dijumpai dalam prasasti Er Hangat (bagian yang memuat angka tahun hilang) Dalam prasasti Er Hangat dia menyebut dirinya Srí Mahäräja Dyah Tagwas Jayakiriwarddhana

10. Nama Rake Panumwangan Dyah Dewendra yang na.k tahta tahun $887 \mathrm{M}$ secara lengkap tıdak dıjumpai dalam prasasti laın. Tetapi nama Dyah Dewendra ditemukan dalam prasastı Poh Dulur 890 M dengan gelar Rake Limus

14. Nama Rake Gurunwangi Dyah Bhadra yang naik tahta tahun $887 \mathrm{M}$ secara lengkap tidak ditemukan dalam prasastı lain. Namun gelar Rake Gurunwangı ditemukan dalam tulisan sıngkat dı candi Plaosan Lor yang menyebut Rake Gurunwangı Dyah Saladu' dan Rake Gurunwang: Dyah Ranu. Selain itu nama Rake Gurunwangı juga ditemukan dalam prasastı Munggu Antan $887 \mathrm{M}$

12. Nama Rake Wungkalhumalang Dyah Jbang yang nalk tahta tahun $894 \mathrm{M}$ tidak dijumpai dalam prasastı laın. Namun demikian dalam prasastı Mantyası 907 M dan prasasti Panunggalan 896 M dijumpai nama Rake Watuhumalang yang merupakan sinonim dari Wungkal humalang.

13 Nama Rake Watukura Dyah Balltung sebagal tokoh yang menerbitkan Prasasti Wanua Tengah III banyak disebut dalam prasastı laın, dı antaranya prasastı Mantyasih. prasastı Watukura $902 \mathrm{~N}$ dan prasasti Poh $905 \mathrm{M}$

Dalam uraıan dı atas dapat dilihat bahwa recualı Rahyangta । Hara dan Dyah Gula, namanama raja atau tokoh yang disebut dalam prasasti Wanua Tengah III juga ditemukan dalam prasastı atau inskrıpsı lain. Hal ini dapat dipakai sebagai dasar untuk mengatakan bahwa prasasti Inı asli sehingga ısınya layak dipercaya sebagai bahan rekonstruksi sejarah raja-raja Mataram Kuna
III. Rekonstruksı Sejarah Raja-raja Mataram Kuna Darı Sañjaya Sampai Balıtung

Prasastı Wanua Tengah III hanya menyebut tentang saat naik tahtanya seorang raja. sedang kapan pemerıntahan mereka berakhır tıdak disebut secara eksplisit. Meskipun demikıan dapat ditafsirkan bahwa masa pemerintahan seorang raja berakhir sebelum atau pada saat raja berikutnya naik tahta. Asumsi inilah yang nanti akan digunakan untuk menghitung lamanya seorang raja memerintah

Berikut ini akan dibahas mengenai hubungan antar raja-raja baik yang disebut dalam prasasti Wanua Tengah III maupun yang disebut dalam prasasti lain. Untuk memudahkan pembahasan uraran akan dilakukan secara kronologis mulai dari Sañjaya, Rake Panangkaran dan seterusnya

\section{Sañjaya}

Menurut prasastı Mantyasih, raja yang berkuasa sebelum Rake Panangkaran adalah Sañjaya. Raja inı telah mengeluarkan prasastı Canggal 732 M. Sañjaya diduga mulaı memerıntah tahun $717 \mathrm{M}$. Dugaan ını didasarkan atas perhitungan permulaan tarıkh Sañjaya yang hanya digunakan oleh Daksottana dı dalam dua prasastinya (Bambang Sumadio, 1992: 100) Jika dugaan inı benar, maka Sañjaya memerıntah antara tahun $717 \mathrm{M}$ sampai sebelum atau pada tahun $746 \mathrm{M}$. Akhir masa pemerıntahannya ditetapkan berdasarkan awal pemerıntahan Rake Panangkaran yang memerintah setelah Sañjaya

Prasasti Wanua Tengah III tidak menyebut nama Sañjaya, namun dapat dipastikan bahwa Rahyangta ri Mdang yang disebut sebagal kakak Rahyangta i Hara adalah Sañjaya Berbeda dengan kakaknya yang beragama Siwa, Rahyangta i Hara memeluk agama Buddha. Hal ını terlihat dari tındakannya mendirikan bihara $d$ Pikatan. Agama yang dianut oleh adık Sañjaya ın sama dengan yang dianut oleh Rake Panangkaran. Oleh sebab itu tıdak mengherankan apabila Rake Panangkaran memberıan sawah di Wanua Tengah sebagai sima bihara di Pikatan Lebih-lebih jika dingat bahwa pendirı bıhara tersebut adalah pamannya sendırı

\section{Rake Panangkaran}

Menurut prasasti Wanua Tengah III, Rake Panangkaran naik tahta tanggal 27 November 746, dan diperkirakan turun tahta sebelum atau pada tanggal 1 Aprıl 784, sehingga dia memerıntah selama \pm 38 tahun. Raja ini telah mengeluarkan prasasti Kalasan 778 M. Kelurak 782 M dan prasasti Ratu Boko atau Abhayagiriwihara 792 M. Prasastı Kalasan dan Kelurak tidak menimbulkan masalah karena dikeluarkan pada saat dia masih memerintah. Sebaliknya prasastı 


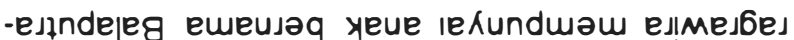

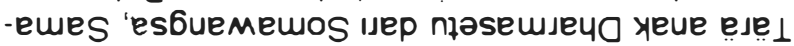

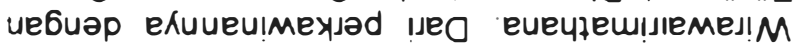
is jejə6ıа 6uen espuəies es6uem

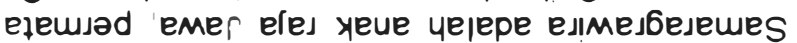
lul lisesejd injnuaw (W OSg $F$ ) epuejeN isesejd wejep ınqәs!p Guex eл!mes6ejewes ue6uəp emes e66unjejemes emyeq jedepurd ue6uәp ninıəs 6unjəpuəo lu!

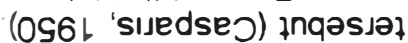
ions ueun6ueq euाs ie6eqəs jeduəł edejəqəq ip

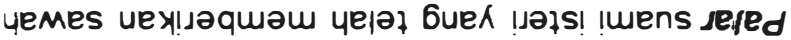
nd vedeled vefeseyey 6uejuəl inqəরuәm euny емег eseyeq

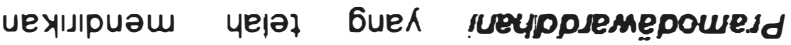
exuyeue uep ebbunjesewes emeusəq

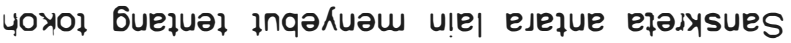
eseyequaq 6uek ueibeg eunty emer eseyeq uep ejəנxysues eseyeq niek eseyeq enp wejep

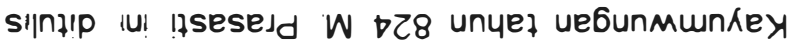

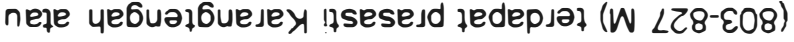
үелем әуеу иeyejulsәmәd esem mejeO ueqejeued әуеу yeue ipeluam sejued 6uemәш уелем

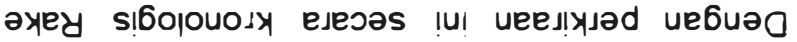
unyet 6t $\mp$ eisn wejep je66uluam uep $W$ 8LL

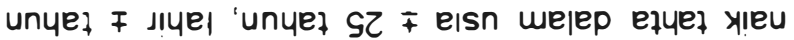

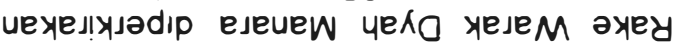
ueqeseued әxеy yeue yejepe yeseM әуеу jesəq ueuix6unməx ul jesep sei甘 yes ejejas ejuej Isisemam

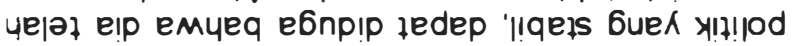
euesens uexjeque66uәm Guek eme| dnत्रno exuneyejulsamad esem je6ul6uәm ue!pnwәy eMIS eme6ejəq uix6unm e!p e66uiyəs (9LL-SLL

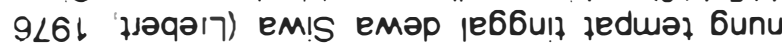
-n6 eweu yejepe esejiey neje esejay esejay! yeunj Gues uełnqəas jedepuəu e!p |e66uluəw ye|

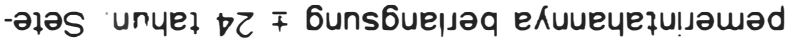
esem !per 128 snisn6ఈ g je66ueł eped neje

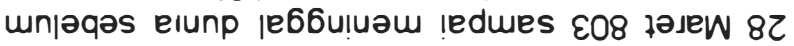
je66uet yejulsәməm iejnu lul eley ekulıp emeu

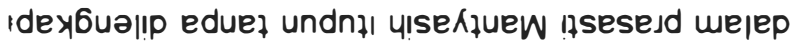
uexnməl!p exuey yejeM әxеy emeu 'III ye6uә। enueM lasesejd wejep inqəsip uiejos

\section{еsеuеw yеко уелем әуеу 'क}

!łsed ue6uәp qeme!! łedep unןәq epnu y'sew e!p ede6uaw eluet ıер !ıp uexנnpun6uәш черә е!p eмyeq e6npip jedep lu! yoхо

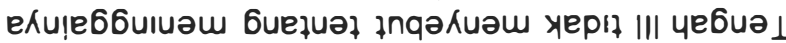

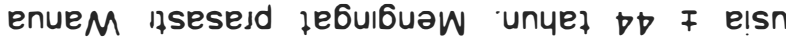
wejep eluet unנni uep $W$ 6SL unyel $\mp$ uexנ!ye|!p eip unyel SC $F$ eisn wejep $W$ b8L unyel eluef ryieu ueqejeued әxеy elexiepu

uesex6ueued әxеy yeue yejepe

ueqejeued әуеу emyeq uee6np jenत्रjəduəw

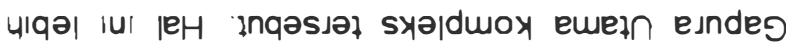

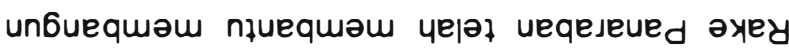
'елеч!м!л6екечq甘 un6uequәш uesexб6ueued әуеу пұуемәs ехеш 'seuәq lu! uee6np eliqedy ueqeseued әуеу yejepe jnqassal

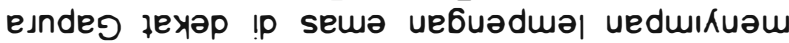
bueh exem 'ueqejeued әуеу uebuәp emes uexsisjej!p jedep uemqejeued exir (ueduls = sed! ejex !jep sedivey) „uedu!kuәw (6uek) UeM -qejeued " uexiluip jedep sedivey uemqejeved

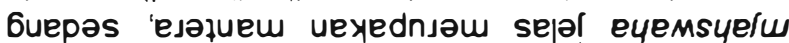
nyiyel wo ( $9 \varepsilon$ :OS6l 'jlweyns) sedivey veM -qejeued eyemsyelw ny!yel wo ues!nnıәəq sema

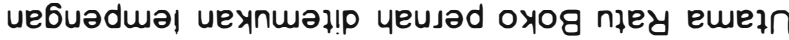
eundes jexәр !p emyeq jejesip nіләd uesex6ueued

әуеу yеuе yерере ueqejeued әуеу emyeq e6npuəw xinun uesejejəq dnxno lu! sesep sef甘 yes Guek eluef sisemad yejepe ueqejeued әуеу ем4еq uexynfunuam snjnu buek isəsyns

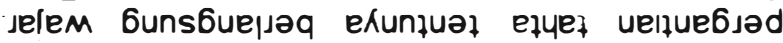
ехеш '!л!p uexunpun6uam exunjnyepuad

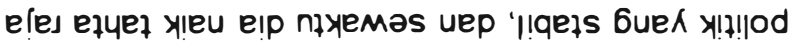
euesens uexjeque66uәm buek emei dnyno ekuueyejulsәməd esem je6uiburw unyej 6 i

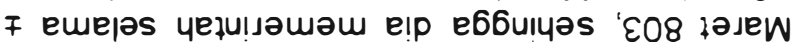
82 je66ueł eped neje unjəqəs ełyeł unjnł $\nabla 8<$

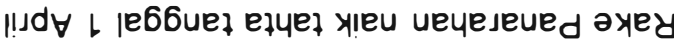
ueqejeued ip undnem ueje66unued !p әxеy ie6eqas jeqeluəm yeusəd lu! yoxol euәsex uexqeqəsip uix6unm epәqләq Guek uejnqakuəd ueqejeued әуеу uebuәp emes ueje66unued әxеy emyeq uexilsedip

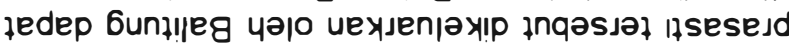
enpax je6uiburw ueqejeued әхеу yеjepe

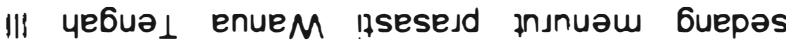
'ueje66unued әуеу черере uesex6ueued әуеу que66uad 4!sekiuew !ssesesd tnunuaw

vegeseued әуеу ' $\varepsilon$

unyeł $b$-99 ejeque exujnun lpsesejd uex

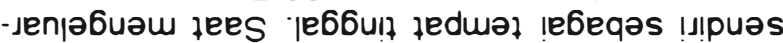
exuuexeun6!p ueu!ry6unwar 6uek oxog niey

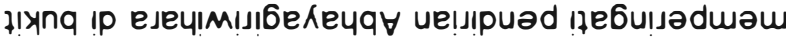
Guek lisesesd uexjenjə6uәm uesex6ueued әуеу ' $W$ Z6L unyet eped emyeq ueejekuәx ue6uәp jenxjəd!p lu! uee6no esey!quәш dnply uep ueyefulıәшәd !sep !ıр uexנnpun6uәш

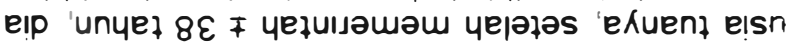
!p emyeq e6npuəw xinjun ueseje sәq dnत्रno 'elunp je66uiuəu uesex6ueued әxеy emyeq uexłnqәs!p yep!| III ye6uә $\perp$ enue $M$ ! unyeł \&9-9s e!snjəq $W \nabla 8 L$ unyeł eped e66ulyəs

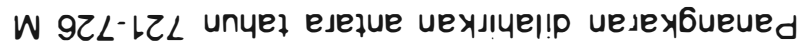
әxey exem unyel $\mathrm{SZ}-0 \mathrm{Z}$ e!sn wejep $9 \nabla \mathrm{L}$ unye?

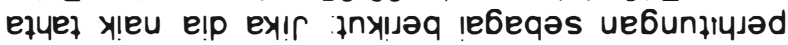
inje|əu uexsejol!p jedep seje ip uejeosjad

ejuet unjni eip

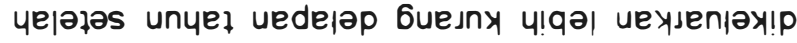
euәsex uejeossəd uexinquilam eseyimisi6e 
dewa yang menjadi raja dı Sriwıjaya. Tokoh yang bergelar Sri Wirawairimathana adalah Rake Panangkaran sehingga Samaragrawira atau Samaratungga adalah anak Rake Panangkaran (Bambang Sumadio, 1992: 112-113)

Untuk lebih meyakinkan bahwa Samaratungga adalah anak Rake Panangkaran, perlu kiranya dilakukan perhitungan kronologi. Menurut prasasti Kayumwungan, pada tahun $824 \mathrm{M}$. Samaratungga telah mempunyai anak Pramodawarddhani yang diperkirakan sudah dewasa namun belum menikah. Jika pada saat itu Pramodawarddhani berusia \pm 18 tahun (dilahirkan sekitar tahun $806 \mathrm{M}$ ) dan pada saat mempunyai anak Samaratungga berusia \pm 25 tahun, maka Samaratungga dilahirkan sekitar tahun 781 M. Pada tahun 781 Rake Panangkaran masih menjadi raja dalam usia \pm 55-60 tahun, sehingga masih mungkin mempunyai anak namun tentunya dengan isteri yang jauh lebih muda usianya. Sebenarnya, jika gelar Sri Wirawairimathana tidak hanya dipakai oleh Rake Panangkaran namun juga dipakai oleh Rake Panaraban, secara kronologis Samaratungga lebih cocok apabila menjadi anak Rake Panaraban

Kini yang menjadi pertanyaan adalah bagaimana sesungguhnya hubungan antara Samaratungga dengan Rake Warak? Dilihat dari agama yang dianut, Samaratungga beragama Buddha dan Rake Warak beragama Siwa, namanama tersebut jelas bukan sebutan untuk tokoh yang sama. Oleh sebab itu perlu dicari kemungkınan lain. Dalam hal ini saya pernah menyatakan bahwa Samaratungga tidak pernah memerintah di Jawa, artinya dia bukan raja Mataram Kuna. Alasannya sebagai berikut: Pada waktu mendirıkan Srimadwenuwana yang memberikan tanah untuk keperluan bangunan suci bukan dia atau anaknya Pramodawarddhani, namun Rakarayan Pu Palar suami isteri. Hal ini menunjukkan bahwa Samaratungga tidak mempunyal hak atas tanah di Jawa artinya dia bukan raja. Oleh karena itu dia meminta bantuan $P u$ Palar suami isteri penguasa setempat untuk menyediakan tanah, sedang yang dilakukannya adalah menyediakan dana pembangunan. Pu Palar kemungkinan adalah seorang kerabatnya yang berasal dari Sumatra yang menduduki jabatan Rakarayan Patapan karena perkawinannya. Dugaan ini muncul karena selain dia mengeluarkan prasasti Sang Hyang Wintang yang berbahasa Melayu Kuna, juga karena selalu menyebut isterinya dalam prasasti-prasastinya (Kayumwungan dan Sang Hyang Wintang). Dugaan bahwa Samaratungga tidak pernah memerintah di Jawa diperkuat dengan kenyataan bahwa namanya hanya disebut dalam prasasti Kayumwungan dan tidak termasuk dalam daftar raja-raja baik yang termuat dalam prasasti
Mantyasih maupun Wanua Tengah lif (Kusen 1988: 7), Dengan demikian apa yang dilakukan oleh Samaratungga dan Pramodawarddhani di daerah Patapan mirip dengan yang dilakukan olek Balaputradewa sewaktu mendirikan bihara di Nalanda. Seperti diketahui bahwa menurut prasasti Nalanda ( $\pm 850 \mathrm{M}$ ), Balaputradewa telah mendirikan bihara di Nalanda sedang tanahnya disediakan oleh Dewapaladewa raja setempat

$\mathrm{Di}$ atas telah disebutkan bahwa Rakarayan Patapan Pu Palar mewarısı pemerintahan di Patapan karena perkawinan Barangkali mertuanya adalah Rakai Patapan Pu Manuku yang disebut dalam prasasti Munduan tahun 807 M. Sewaktu Pu Palar mengeluarkan prasasti Gondosuli mertua laki-lakinya sudah meninggal sehingga namanya tidak disebut dalam prasasti, yang disebut hanya ibunya, ibu mertua, adik, ipar, paman dan anak-anaknya (mengenai isi prasasti Gondosuli lihat Casparis,1950: 61-62, dan Machi Suhadı dan M.M. Soekarto, 1986: 9-10).

Apabila rekonstruksi di atas benar, maka Samaratungga masih terhitung paman Rake Warak, meskipun dari segı usıa mereka sebaya Melihat hubungan persaudaraan mereka perlu dipertanyakan mengapa Samaratungga tidak meminta bantuan Rake Warak namun justru kepada Pu Palar? Salah satu kemungkinan yang terjadi adalah hubungan mereka kurang baık. Retaknya hubungan dapat terjadi karena keputusan Rake Warak mencabut status sawah di Wanua Tengah sebagai sima bihara di Pikatan. Sebagai seorang yang beragama Buddha dan sebagai anak Rake Panangkaran yang dahulu memberikan sawah tersebut kepada bihara di Pikatan, Samaratungga tentu tidak senang dengan keputusan Rake Warak tersebut

Hasil rekonstruksi di atas menunjukkan bahwa Samaratungga tıdak pernah memerıntah di Jawa tetapi kemungkinan besar memerintah di Sumatra. Tokoh ini dapat memerintah di Sumatra (Sriwijaya) selain karena perkawınannya dengan Tara anak Dharmmasetu juga mungkin karena ibunya berasal dari Sumatra. Hal yang terakhır inı dapat dikaitkan dengan isi prasasti Ligor $775 \mathrm{M}$ yang memberi petunjuk bahwa pada saat itu Rake Panangkaran pernah menaklukkan kawasan Sriwıjaya. Kemudian dari sana Rake Panangkaran mcngambil seorang isterı yang akhirnya melahirkan Samaratungga pada sekitar tahun $781 \mathrm{M}$

\section{Dyah Gula}

Menurut prasasti Wanua Tengah III, raja yang naik tahta setelah Rake Warak menınggal adalah Dyah Gula. Tokoh ini hanya memerıntah selama kurang lebih enam bulan (5 Agustus 827 -24 Januari 828). Prasasti Wanua Tengah III 
adalah satu-satunya sumber sejarah yang menyebut Dyah Gula sehingga belum mungkin memecahkan asal-usulnya dengan menggunakan sumber lain sebagai data pembanding. Meskipun demikian petunjuk dalam prasasti Wanua Tengah III dapat digunakan untuk mengidentifikasi siapa dia sebenarnya. Petunjuk tersebut: a Dia naik tahta setelah Rake Warak meninggal, b. Dia belum memiliki gelar Rake, c. kebijaksanaannya terhadap status sawah di Wanua Tengah sama dengan Rake Warak. Berdasarkan ketiga hal ini dapat diduga bahwa Dyah Gula adalah putera mahkota Rake Warak yang ketika ayahnya meninggal masih berusia muda sehingga belum mempunyai wilayah kekuasaan sendiri (Kusen, 1988: 8)

\section{Rake Garung}

Rake Garung naik tahta tanggal 24 Januari 828 dan memerintah sampai meninggal dunia sebelum atau pada tanggal 22 Februari 847 sehingga masa pemerintahannya berlangsung lebih kurang 19 tahun. Melihat masa pemerintahan raja pendahulunya sangat singkat maka diduga Rake Garung naik tahta dengan jalan merebut kekuasaan. Meskipun cara naik tahtanya tidak wajar, namun ternyata dia mampu memerintah dalam kurun waktu yang cukup lama bahkan sampai meninggal dunia. $\mathrm{Hal}$ in menunjukkan bahwa kedudukannya cukup kuat.

Siapa sesungguhnya Rake Garung dan bagaimana hubungannya dengan raja-raja pendahulunya Menurut prasasti Wanua Tengah III, Rake Garung disebut sebagai anak sang lumah i tuk. Siapa sang lumah i tuk belum diketahui karena tidak ada sumber lain yang pernah menyebutnya. Meskipun demikian melihat kedudukannya yang kuat dan lebih kurang setahun setelah naik tahta Rake Garung mengembalikan status sıma-sawah di Wanua Tengah yang sebelumnya dicabut oleh Rake Warak, maka orang tuanya kemungkinan besar adalah raja yang bertahta sebelum Rake Warak yaitu Rake Panaraban.

Untuk memperkuat dugaan di atas perlu dilakukan perhitungan kronologi sebagai berikut: Sebelum menjadi raja Rake Garung pernah mengeluarkan prasasti tahun 819 M (OV., 1920: 136). Jika pada tahun $819 \mathrm{M}$ dia berusia \pm 25 tahun, maka Rake Garung dilahirkan sekitar tahun 794 M. Pada tahun 794 M, usia Rake Panaraban \pm 35 tahun sehingga dari segi usia Rake Panaraban pantas menjadi ayah Rake Garung.

Apabıla dugaan di atas benar maka Rake Garung adalah adik Rake Warak dan masih terhitung paman dari Dyah Gula. Dengan demikian agaknya Rake Garung telah merebut tahta dari tangan kemenakannya sendirı yang pada saat naik tahta masih berusia muda.

Pada masa pemerintahan Rake Garung terdapat prasasti Tru i Tpussan 842 M yang menyebut nama Sri Kahulunnan ( Casparis, 1950: 86-87). Menurut Boechari, Sri Kahulunnan berarti ibu suri (Boechari, 1982: 17-18). Dengan demikian Sri Kahulunnan adalah ibu Rake Garung, atau janda Rake Panaraban. Apabila Sri Kahulunnan melahirkan Rake Garung \pm tahun 794 M dalam usia \pm 18 tahun, maka pada tahun 842 M usianya \pm 66 tahun dan dia lahir sekitar tahun 776 M. Perkiraan tahun kelahiran Sri Kahulunnan ini memberi petunjuk bahwa dia bukan ibu Rake Warak, karena menurut perhitungan dı depan Rake Warak dilahirkan sekitar tahun 778 M. Dengan demikian Rake Garung adalah saudara tiri Rake Warak

Nama Sri Kahulunnan tertulis pada tulisan singkat yang terdapat di kompleks candı Plaosan Lor. Jika dia ibu Rake Garung, maka Sri Maharaja yang terdapat dalam tulisan-tulisan singkat candi Plaosan Lor (kecuali Sri Maharaja Rake Pikatan) bukan Rake Pikatan namun Rake Garung. Dugaan ini didukung oleh data yang terdapat di dalam prasasti Wanua Tengah III Seperti telah disebutkan didepan bahwa dalam prasasti Wanua Tengah III terdapat kutipan dari prasasti Rake Garung yang berangka tahun 829 $M$. Di dalam kutipan tersebut terdapat nama Sirikan Pu Suryya sebagai salah satu pejabat yang menyertai Rake Garung sewaktu mengembalikan sawah di Wanua Tengah kepada bihara di Pikatan. Ternyata bahwa di candi Plaosan Lor yaitu pada candi perwara deret I No. 15 dan 16 juga terdapat tulisan Sang Sirikan Pu Suryya. Jika Sirikan Pu Suryya yang terdapat dalam prasasti Wanua Tengah III dan di candi Plaosan Lor tersebut sama orangnya, maka dugaan di atas menjadi cukup kuat (Kusen, 1988: 10)

\section{Rake Pikatan Dyah Saladu}

Setelah Rake Garung wafat, yang kemudian naik tahta adalah Rake PIkatan Dyah Saladu. Raja ini naik tahta pada tanggal 22 Februari 847 dan memerintah sampas meninggal dunia sebelum atau pada tanggal 27 Meı 855 M. sehingga masa pemerintahannya berlangsung $\ddagger$ delapan tahun

Kebijaksanaan Rake Pikatan Dyah Saladu terhadap status sawah di Wanua Tengah berbeda dengan Rake Garung. Jika Rake Garung memulihkan status sıma sawah yang dahulu dicabut oleh Rake Warak, Rake Pikatan kembali mencabut status sima tersebut Perbedaan kebijaksanaan inı mungkın ada sangkut-pautnya dengan hubungan Rake Pikatan Dyah Saladu dengan raja-raja pendahulunya. Oleh sebab itu berikut ini akan dicarı asal-usul Dyah Saladu 
berdasarkan sumber-sumber sejarah yang tersedia.

Selain dalam prasasti Wanua Tengah III, nama Dyah Saiadu tertulis pada bagian harmika dua buah stupa perwara candi Plaosan lor. Nama tersebut terangkaı dalam tulisan anumoda raḱe gurunwangi dyah saladu astupa sri maharaja rake pikatan (Casparis, 1958: 11). Meskipun Saladu di Plaosan Lor ditulis dengan u (panjang) dan dalam prasasti Wanua Tengah III ditulis dengan u (pendek) serta di Plaosan Lor bergelar Rake Gurunwangi dan dalam Wanua Tengah III bergelar Rake Pikatan, namun diduga hanya menunjuk orang yang sama. Pada waktu berlangsungnya pembangunan kompleks Plaosan Lor, Dyah Saladu masih menjabat sebagai Rake Gurunwangi dan menyumbang pembangunan dua buah stupa perwara (deret III, no. 14 dan 15) Ketika Rake Garung wafat, Dyah Saladu berhasil naik tahta dan daerah kerakeannya pındah ke Pikatan. Setelah naik tahta tampaknya dia merasa perlu untuk mencantumkan gelar dan kedudukannya yang baru pada kedua stupa perwara yang didirıkannya ketika masih menjabat sebagai Rake Gurunwangi (Kusen, 1986: 408; 1988: 11).

Di candi Plaosan Lor selain Rake Gurunwangi Dyah Saladu ditemukan juga nama Rake Gurunwangi Dyah Ranu. Diduga Dyah Ranu adalah ayah dari Dyah Saladu yang setelah membangun candi pervara di Plaosan Lor mengundurkan dirı dan menyerahkan kekuasaan dı Gurunwangı kepada anaknya. Dyah Saladu yang menjabat sebagaı Rake Gurunwangi kemudian ikut mengambil bagıan dalam pembangunan candı Plaosan Lor yang sewaktu dia mewarisi kedudukan ayahnya belum selesai dibangun.

Selanjutnya keputusan Rake Pikatan Dyah Saladu untuk mencabut kembali status sima sawah di Wanua Tengah memberi petunjuk bahwa dia memılıkı hubungan dekat dengan Rake Warak, kemungkinan adalah menantunya. Secara kronologi Rake Pikatan Dyah Saladu memang mungkin menjadi menantu Rake Warak Hal inı dapat ditunjukkan melalui perkiraan perhitungan sebagai berikut: Pada tahun 855 M, ketika Rake Pikatan Dyah Saladu meninggal dunia anaknya yang muda yaitu Rake Kayuwangi Dyah Lokapala telah dewasa. Jika saat itu Dyah Lokapala berusia \pm 25 tahun dan sewaktu anaknya yang muda lahir Dyah Saladu berusia \pm 25 tahun, maka Dyah Saladu kira-kira dilahirkan tahun $805 \mathrm{M}$. Pada tahun 805 M usia Rake Warak \pm 27 tahun. Dengan demikian dari segi usia Dyah Saladu pantas menjadi menantu Rake Warak. Isteri Dvah Saladu adalah adik atau kakak Dyah Gula

Dalam masa pemerıntahan Rake Pikatan Dyah Saladu yaitu padd tahun 850 M terbit prasasti Tulang Air. Prasastı inı dikeluarkan oleh Rake Patapan Pu Manuku. Nama Pu Manuku selain dijumpai dalam prasasti Tulang air, juga dijumpai dalam prasasti Munduan $807 \mathrm{M}$ dan prasasti Wanua Tengah I 863 M. Seperti halnya dalam prasasti Tulang Air, dalam prasastı Munduan Pu Manuku menjabat sebagai Rake Patapan, sedang dalam prasasti Wanua Tengah I dia menjabat sebagai Rake Pikatan. Ditinjau dari hitungan waktu jelas bahwa Pu Manuku yang disebut dalam prasasti Munduan berbeda orangnya dengan yang disebut dalam prasastı Tulang Air. Lebih-lebih apabila diingat bahwa di antara mereka terselip nama pu Palar sebagai penguasa di Patapan, Sebaliknya Pu Manuku yang disebut dalam prasasti Tulang Air dan Wanua Tengah I, meskıpun yang satu bergelar Rake Patapan sedang yang lain bergelar Rake Pikatan, namun kemungkinan adalah orang yang sama.

Berdasarkan uraian dı atas diduga bahwa Rake patanan Pu Manuku yang disebut dalam prasasti Tulang Air $850 \mathrm{M}$ atau Rake Pikatan yang disebut dalam prasasti Wanua Tengah I 863 $M$, adalah anak Pu Palar yang menikah dengan anak Rake Pikatan Dyah Saladu. Penjelasan mengenai dugaan ini sebagar berikut. Di dalam prasasti Gondosuli (Sang Hyang Wintang) disebutkan bahwa Pu Palar mempunya: lima orang anak. Anak sulungnya kemudian menggantikan kedudukan orang tuanya sebagaı Rake Patapan dan menggantı namanya sama dengan nama kakeknya yaitu Pu Manuku Sebelum menjadi Rake Patapan, Pu Manuku telah menikah dengan anak Rake Pikatan Dyah Saladu. Istrinya kemungkinan besar adalah kakak Dyaj Lokapala. Pada tahun 850 M, usıa Pu Manuku diperkirakan \pm 25 tahun sehingga dia dilahirkan sekitar tahun 825 M Perkiraan tahun kelahiran Inı cocok dengan ISI prasast Kayumwungan (Karangtengah) $824 \mathrm{M}$ yang tidak menyebutkan bahwa Pu Palar suami istrı sudah mempunyai anak. Ketıka mertuanya meninggal dunia di tahun 855 M, daerah Pikatan tidak ada kepala daerahnya, sehingga Pu Manuku menggantikan mertuanya sebagai Rake Pikatan Jabatannya sebagai Rake Pikatan terus berlangsung sampai dengan tahun $863 \mathrm{M}$ ketika dia menerbitkan prasasti Wanua Tengah! Pada saat prasasti tersebut diterbitkan yang menjadı raja adalah adik iparnya sendiri yaitu Rake Kayuwangi Dyah Lokapala.

Setelah asal-usul dan kemungkinan hubungan Rake Pikatan Dyah Saladu dengan tokoh--tokoh yang sejaman dibahas, masih ada hal yang perlu dipertanyakan yaitu mengapa dia dapat naik tahta menggantikan kedudukan Rake Garung. Keterangan langsung mengenai hal inı belum ditemukan. Namun demikian ada 
kemungkınan bahwa dia berhasıl naik tahta dengan jalan merebutnya dari tangan pewaris yang sah. Dugaan ini muncul karena dalam prasasti Siwagrha $856 \mathrm{M}$ tersirat adanya peperangan yang terjadi sebelum Rake Kayuwangi Dyah Lokapala naık tahta (Casparis, 1956: 316-319). Peperangan ini kemungkinan terjadi karena pertentangan yang berkelanjutan antara keturunan Rake Garung dengan Rake Pikatan Dyah Saladu sebagai akibat Dyah Saladu merebut tahta. Perang inilah yang ke- mungkinan menyebabkan kematian Rake Pikatan Dyh Saladu pada tahun $855 \mathrm{M}$.

Rekonstruksi di atas berbeda dengan rekonstruksi Casparis. Menurut Casparis, Rake Pikatan (dalam prasastı Siwagrha disebut Jatinıngrat) mengundurkan diri dari tahta Pendapat ini didasarkan atas penafsiran kata "uparata" yang menurut Casparıs berarti mengundurkan diri (Casparıs, 1956: 288). Berbeda dengan Casparıs, Boechari menafsirkan kata "uparata" sebagai meninggal dunia (Boechari, t.t.: V.33 ; Bambang Sumadio, 1992) Dalam hal ini rupa-rupanya pendapata Boechari yang benar karena dalam prasasti Wanua Tengah III jelas disebutkan bahwa Rake Pikatan Dyah Saladu meninggal sebelum Rake Kayuwangi naik tahta

\section{Rake Kayuwangi Dyah Lokapala}

Rake Kayuwangi naık tahta tanggal 27 Mel 855 setelah meninggalnya Rake Pikatan Dyah Saladu. Dia memerintah sampai meninggal dunia sebelum atau pada tanggal 5 Februari 885 Dengan demikıan dia memerintah selama \pm 30 tahun

Rake Kayuwangi Dyah Lokapala dildentifikasi sebagai anak Rake Pikatan Dyah Saladu (Bambang Sumadio, 1992: 127-128). Hal Ini tidak perlu dipersoalkan lebih lanjut karena tampaknya memang benar. Demikian pula pendapat Casparis yang berkaitan dengan identifikasi kata walaputera dalam prasasti Siwagrha dengan Baliaputradewa yang disebut dalam prasasti Nalanda dan peperangan yang terjadı antara Balaputradewa dari dinasti Sailendra dengan Rake Kayuwangi dan Rake Pikatan (Casparis, 1956 289-294), tidak perlu lagı diulas sebab darı rekonstruksi yang telah disajikan di depan jelas bahwa Balaputradewa tidak pernah memerintah di Jawa. Adapun yang perlu dipermasalahkan adalah jatidiri Rakai Walaıng Pu Kumbhayoni yang hidup sejaman dengan Rake Kayuwangi.

Meskipun Rake Walaing Pu Kumbhayoni disebut dalam beberapa prasasti, namun asalusul dan hubungannya dengan raja-raja Mataram kuna belum jelas. Dalam prasasti Pereng (Wukıran) $863 \mathrm{M}$, dia menyebut dirinya sebagai cicit Sang Ratu I Halu. Menurut Boecharı kemubngkinan besar Sang Ratu \& Halu adalah adik Rakai Mataram Sang Ratu Sañjaya (Bambang Sumadio, 1992:131-132). Pertanyaan yang muncul adalah apakah Sang Ratu I Halu sama dengan Rahyangta , Hara yang dalam prasasti Wanua Tengah III disebut sebagai adik Rahyangtia ri Mdang ? Sebelum ditemukan petunjuk yang lebih jelas, masalah inı tetap merupakan pertanyaan yang tidak terjawab. Demikian pula perbedaan pendapat antara Casparis dan Boechari dalam mengıdentifikasikan jatidiri Rake Walaing tak akan pernah terselesaikan sebelum ada data baru yang dapat menjelaskan persoalan ini. Seperti diketahui Casparis menduga bahwa Rake Walaing adalah rake Pikatan setelah mengundurkan dir (Casparis, 1956: 289-294), sedang Boechari cenderung berpendapat bahwa Rake Walaing justru musuh Rake Pikatan dan Rake Kayuwang: yang disebut dalam prasasti Siwagrha (Boecharim t.t: V.38). Jika kemudian terbukt bahwa pendapat Boechari yang benar, apakah Rake Walaing justru anak Rake Garung yang haknya atas tahta direbut oleh Rake Pikatan?

\section{Dyah Tagwias}

Menurut prasasti Wanua Tengah Iil Dyah Tagwas naik tahta tanggal 5 Februarı 885 setelah wafatnya Rake Kayuwangi. Masa pemerıntahan tokoh ini hanya berlangsung sampal atau sebelum tanggal 27 September 885 sehıngga dia hanya memerintah selama \pm delapan bulan Dyah Tagwas turun tahta karena digulıngkan Mengingat dia naik tahta setelah meninggalnya Rake Kayuwangi dan belum memakai gelar Rake, maka diduga bahwa Dyah Tagwas adalah anak Rake Kayuwangi yang pada saat ayahnya meninggal belum benar-benar dewasa

Selain dalam prasasti Wanua Tengah ili nama Dyah Tagwas dijumpai dalam prasastı Er Hangat Dalam prasasti ini dia menyebut dirinya Sri Maharaja Dyah Tagwas Jayakirti-warddhana (OJO. CIV). Sayang bahwa bagian prasasti Er Hangat yang memuat angka tahun belum ditemukan sehingga kapan prasasti ini diterbitkan belum diketahui. Menurut perkıraan jones prasasti Er Hangat berasal dari \pm tahun $888 \mathrm{M}$ (Jones, 1984: 19). Jika perkiraan Jones benar maka berarti bahwa setelah digulingkan Dyan Tagwas tetap menyatakan dirinya sebagaı raja dengan mengeluarkan prasastı Er Hangat tersebut. Jika perkiraan Jones salah maka prasastı Er Hangat tentunya dikeluarkan antara tanggal 5 Februari - 27 September 885

Menarik perhatian bahwa dalam prasast Er Hangat disebut-sebut tentang adanya guru hyang i kelasa yang menerıma pasek-pasek sebesar 4 masa. Hal ini mengingatkan kepada 
sebutan Rake Warak Dyah Manara setelah meninggal dunia yaitu sang lumah i kelasa. Jika Kelasa yang disebut dalam prasastı Wanua Tengah III sama dengan yang disebut dalam prasasti Er Hangat, maka dugaan bahwa Rake Pikatan Dyah Saladu (kakek Dyah Tagwas) menantu Rake Warak menjadi lebih kuat (Kusen, 1988: 15)

\section{Rake Panumwangan Dyah Dewendra}

Menurut prasasti Wanua Tengah III, setelah Dyah Tagwas terguling dari tahta yang kemudian naik tahta adalah Rake Panumwangan Dyah Dewendra. Raja ini naik tahta tanggal 27 September 885 dan terpaksa turun tahta karena digulingkan sebelum atau pada tanggal 27 Januari 887 . Dengan demikian masa pemerintahannya hanya berlangsung \pm satu tahun empat bulan.

Mengingat Dyah Dewendra naik tahta setelah Dyah Tagwas digulingkan, maka dapat dipastikan bahwa Dyah Dewendra inilah yang telah merebut kekuasaan dari tangan Dyah Tagwas. Menarik perhatian bahwa setelah digulingkan, Dyah Dewendra masih mengeluarkan prasasti Poh Dulur pada tahun 890 $M$ dan menyebut dirinya Rake Limus Dyah Dewendra (Jones, 1984: 197-198). Berpindahnya kraton Dyah Dewendra dari Panumwangan ke Limus mungkin disebabkan karena kratonnya yang berada di Panumwangan dianggap tidak layak dihunı karena pernah diduduki musuh.

Siapa sebenarnya Dyah Dewendra dan bagaimana hubungannya dengan penguasapenguasa terdahulu belum diketahui dengan pasti karena belum ada data yang dapat digunakan untuk menjelaskannya. Mungkin dia masih keturunan Rake Garung yang jalur pewarisan tahtanya dipotong oleh Rake Pikatan Dyah Saladu, atau dia justru kakak ıpar Dyah Tagwas sendiri yang merasa lebih pantas mewarisi tahta dibandingkan saudara iparnya yang masih sangat muda

\section{Rake Gurunwangi Dyah Bhadra}

Rake Gurunwangi Dyah Bhadra naik tahta tanggal 27 Januari 887 segera setelah Rake Panumwangan Dyah Dewendra terguling dari tahta. Meskipun dalam prasasti Wanua Tengah III tidak disebutkan tetapi jelas. bahwa Dyah Bhadra Inilah yang telah merebut kekuasaan dari tangan Dyah Dewendra. Namun demikian ternyata setelah bertahta selama 28 hari, Dyah Bhadra terpaksa melarikan diri dari istana (naik tahta 27 Januari, melarikan diri 24 Februari 887). Setelah Dyah Bhadra meninggalkan istana, kerajaan tidak ada yang memerintah ("... anayaka ta ikanaing rat rikang kala ..."

Sangat menarik perhatian bahwa meskipun masa pemerintahannya sangat singkat namun Rake Gurunwangi sempat mengeluarkan prasasti Munggu Antan pada tanggal 9 Februar 887 (Bambang Sumadio, 1992: 134; OJO, XVIII) Penerbitan prasasti ini agaknya merupakan suatu langkah politik untuk memperkokoh kedudukannya; tetapi rupa-rupanya tidak berhasil.

Bagaimana hubungan Rake Gurunwang। Dyah Bhadra dengan raja-raja pendahulunya hanya dapat diperkırakan melalui jabatannya sebagai Rake Gurunwangi Apapun bentuknya Dyah Bhadra tentu mempunyar hubungan khusus dengan Rake Gurunwangi Dyah Saladu (Rake Pikatan Dyah Saladu). Mungkin sebagai anak. mungkin sebagai cucu Dyah Saladu

\section{Rake Wungkafhumalang Dyah Jbang}

Setelah Rake Gurunwangi Dyah Bhadra meninggalkan istana pada tanggal 24 Februarı 887, tahta kerajaan koson selama tujuh tahun Masa kosong ini berakhir ketika Rake Wungkalhumalang naik tahta pada tanggal 27 November 894. Raja baru ini memerintah sampaı meninggal dunia sebelum atau pada tanggal 23 Mei 898 .

Dalam prasasti Mantyasih 907 M, nama Rake Wungkalhumalang tidak tercantum, yang tercantum adalah nama Rake Watuhumalang Mengingat kata wungkal sinonim dengan watu maka Rake Wungkalhumalang sama orangnya dengan Rake Watuhumalang. Selaın disebut dalam prasasti Mantyasih, Rake Watuhumalang juga disebut dalam prasasti Panunggalan 896 dengan gelar haji (Bambang Sumadio, 1992 135).

Bagaimana hubungan tokoh ini dengan raja-raja sebelumnya dan bagaimana dia berhasıl naik tahta belum dapat dijelaskan. Meskipun demikian rasa-rasanya dia masih memilik: hubungan kekeluargaan dengan salah satu dı antara raja-raja pendahulunya

\section{Rake Watukura Dyah Balitung}

Menurut prasasti Wanua Tengah III setelah meninggalnya Rake Wungkalhumaiang yang kemudian naik tahta adalah Rake Watukura Dyah Balitung. Raja ini naik tahta pada tanggal 23 Mei 898. Pada tahun 904 M, Balitung menurunkan perintah agar seluruh sanghyang dharma bihara di Jawa dijadikan swatantra. Selanjutnya pada tanggal 1 Oktober 908, Balıtung mengembalikan sawah di Wanua Tengah sebagai sima bihara di Pikatan. Di samping halhal tersebut di atas, dalam prasasti Wanua Tengah III terdapat satu hal yang sangat menarik perhatian yaitu dikutipnya prasasti Rake Garung baik dalam versi Sanskreta maupun Jawa kuna Prasasti Rake Garung yang dikutp ını pada pokoknya berisi keputusan Rake Garung untuk 
memulinkan status sıma di Wanua Tengah yang sebelumnya dicabut oleh Rakai Warak. Hal ini mungkın dapat dipakai sebagai petunjuk bahwa Balitung mempunyai hubungan khusus dengan Rake Garung

\section{Kesimpulan}

Dari pembahasan di depan dapat ditarık kesımpulan sebagai berikut:

1. Perbedaan daftar nama raja-raja dalam prasastı Mantyasih 907 M dengan Wanua Tengah III 908 disebebkan perbedaan latar belakang dikeluarkannya prasasti

Prasasti Mantyasih diterbitkan dalam rangka melegitimasikan dirinya sebaga pewaris tahta yang syah, sehingga yang dicantumkan hanya para raja yang berdaulat penuh atas seluruh wilayah kerajaan. Dyah Gula, Dyah Tagwas, Dyah Dewendra dan Dyag Badhra tidak dimasukkan dalam daftar karena mereka tidak pernah berdaulat penuh atas wilayah kerajaan. Hal ini terlihat darı singkatnya masa pemerintahan mereka karena digulingkan dari tahta

Prasastı Wanua Tengah III dikeluarkan daiam kaitannya dengan perubahanperubahan status sawah di Wanua Tengah, sehıngga semua penguasa yang mempunyaı sangkut pait dengan perubahan status sawah dimasukkan dalam daftar. Nama Sañjaya tidak disebut karena riwayat sawah di Wanua Tengah baru dimulai dari masa Rake Fanangkaran

2 Prasastı Wanua Tengah III sungguh merupakan bukti sejarah yang sangat penting. sehingga perlu diperhitungkan dalam rekonstruksı sejarah raja-raja Mataram Kuna

Salah satu hal penting yang dapat ditarik darı ISI prasastı Wanua Tengah III adalah kenyataan bahwa pergantian raja-raja Mataram Kuna tidak selalu berjalan mulus Perebutan tahta serıng terjadi. dari hasil rekonstruksı dapat diketahui bahwa perebutan kekuasaan terjadı di antara keluarga keturunan Sañjaya dan bukan karena pertentangan antara dinasti Sailendra dengan dınasti Sañjaya

\section{KEPUSTAKAAN}

Bambang Sumadio (ed), 1977. Sejarah Nasional Indonesia II, Jakarta: Balai Pustaka.

-Bambang Sumadio, 1992.Sejarah Nasional Indonesia II Edisi ke-4, Jakarta: Balai Pustaka
Boechari, 1965. Epigraphy and indonesian Historiograph, dalam Soedjatmoko et al. An Introduction to Indonesian Historiogra. phy, Ithaca: Cornell University, hlm.47-73

Boechari, tt Sailendrawrangsa dan Isanawangsa naskah

Boechari, 1982 Aneka Cataan Epıgrafı dan Sejarah Kuna Indonesıa, Majalah Arkeologi, Th. V, No. 1-2, hlm 15-38

Boechari dan A.S Wibowo, 1986 Prasasti Koleksi Museum Nasional, Jilid I Jakarta: Proyek Pengembangan Museum Nasional.

Casparis, J.G de, 1950. Prasasti Indonesıa I Bandung. A.C Nix \& Co

Casparis, 1956 Prasasti Indonesia II, Bandung Masa Baru

Casparis: 1958 Short Inscription from Tjand Plaosan Lor Berita Dinas Purbakala No. 4 Djakarta. Dinas Purbakala

Djoko Dwiyanto, 1985. Penemuan Beberapa Prasastı Baru Sebagar Sumbangan Bagi Historiografi indonesia, Makalah Seminar Sejarah Nasional IV di Yogyakarta

Djoko Dwiyanto, 1986. Pengamatan Terhadap Data Kesejarahan Darı Prasastı Wanua Tengah III Tahun 908 M, Pertemuan IImiah Arkeologi IV, Buku lla, Jakarta, hIm 92-110

Gosta Lieber, 1976. Iconographic Dictionary of the Indian Religion, Leiden E J Brill

Hasan Djafar, 1985. Prasastı dan Historıografı Makalah Seminar Sejarah Nasional IV di Yogyakarta

Jones, A.M.B. 1984. Early Tenth Centun vava from the Inscriptions a Study of Econo. mic, Social and Administrative Condstrons in the First Quarter of the Century. VKI 107, Dordrecht: Foris Publication

Kusen,1984.Temuan Baru dari Temanggung Prasasti Raja Balitung 830 Saka, Kompas, Mınggu, 6 Meı 1984

Kusen,1986 Parit Keliling Candi Plaosan Lor Pertemuan IImiah Arkeologi IV, Buku Ilb, Jakarta, hlm 397-412 
Kusen, 1988 Prasastı Wanua Tengah III 830 Saka. Studi Tentang Latar Belakang Perubahan Status Sawah di Wanua Tengah Sejak Rake Panangkaran Sampai Rake Watukura Dyah Balitung, Makalah dalam Kegiatan IImiah Arkeologi IAAI Komisariat DIY Jawa Tengah di Yogyakarta.

-Kusen. 1989. Faktor-faktior Penyebab Terjadinya Perubahan Status Sawah di Wanua Te ngah Dalam Masa Pemerintahan Rajaraja Mataram Kuna Abad 8-10, Laporan Penelitian Fakultas Sastra UGM.

Machi Suhadi dan M.M. Soekarto, 1986. Laporan Penelitian Epigrafi Jawa Tengah, Berita Penelitian Arkeologi No. 37, Jakarta Pusat Penelitian Arkeologi Nasional

Oud Javaansche Oorkonden, Nagelaten transcripties van wijlen Dr J.L.A. Brandes, uitgegeven door Dr. N.J. Krom, VBG, IX, 1913, 's- Gravenhage: Martinus Nijhoff.
Soekmono, 1965. Archaeology and indonesian History, dalam Soedljatmoko, et al. An Introduction to Indonesian Historiography, Ithaca: Cornell University, him 36-46

Suhamir, 1950. Verslag van de werkzaamheden van de voormalige Bouwkundige Afdeling van de Oudheidkundige Dienst van 8 Maart 1942 tot 19 December 1948, Oudheidkundig Verslag 1948, Bandung A.C. Nix \& Co, hlm. 20-41

Wojowasito, S., 1977. Kamus Kawi-Indonesia, Bandung: CV Pengarang.

Zoetmulder, P.J., 1982. Old Javanese-English Dictionary. 's-Gravenhage: Martinus Nijhoff. 


\section{Prasastı Mantyasıh 907 M}

Rakaı Mataram Sang Ratu Sañjaya

Srı Maharaja Rakai Panangkaran

Srı Maharaja Rakaı Panunggalan

Srı Maharaja Rakai Warak

Srı Maharaja Rakaı Garung

Srı Maharaja Rakai Pikatan

Srı Maharaja Rakaı Kayuwangi

Srı Maharaja Rakaı Watuhumalang

Sri Maharaja Rakai Watukura

Dyah Balitung
Prasasti Wanua Tengah III 908 M

Rahyangta ri Mdang

Rake Panangkaran

(7-10-746 s/d 1-4-784)

Rake Panaraban

(1-4-784 s/d 28-3-803)

Rake Warak Dyah Manara

(28-3-803 s/d 5-8-827)

Dyah Gula

(5-8-827 s/d 24-1-828)

Rake Garung

(24-9-828 s/d 22-2-847)

Rake Pikatan Dyah Saladu

(22-2-847 s/d 27-5-855)

Rake Kayuwangı Dyah Lokapala (27-5-855 s/d 5-2-885)

Dyah Tagwas

(5-2-885 s/d 27-9-885)

Rake Panumwangan Dyah Dewendra (27-9--885 s/d 27-1-887)

Rake Gurunwangı Dyah Bhadra (27-1-887 s/d 24-2-887)

Rake Wungkalhumalang Dyah Jbang (27-11-894 s/d 23-5-898)

Rake Watukura Dyah Balitung (23-5-898 s/d 1-10-908) 


\section{LAMPIRAN 2}

\section{REKONSTRUKSI HUBUNGAN RAJA-RAJA MATARAM KUNA DARI SAÑJAYA SAMPAI BALITUNG}

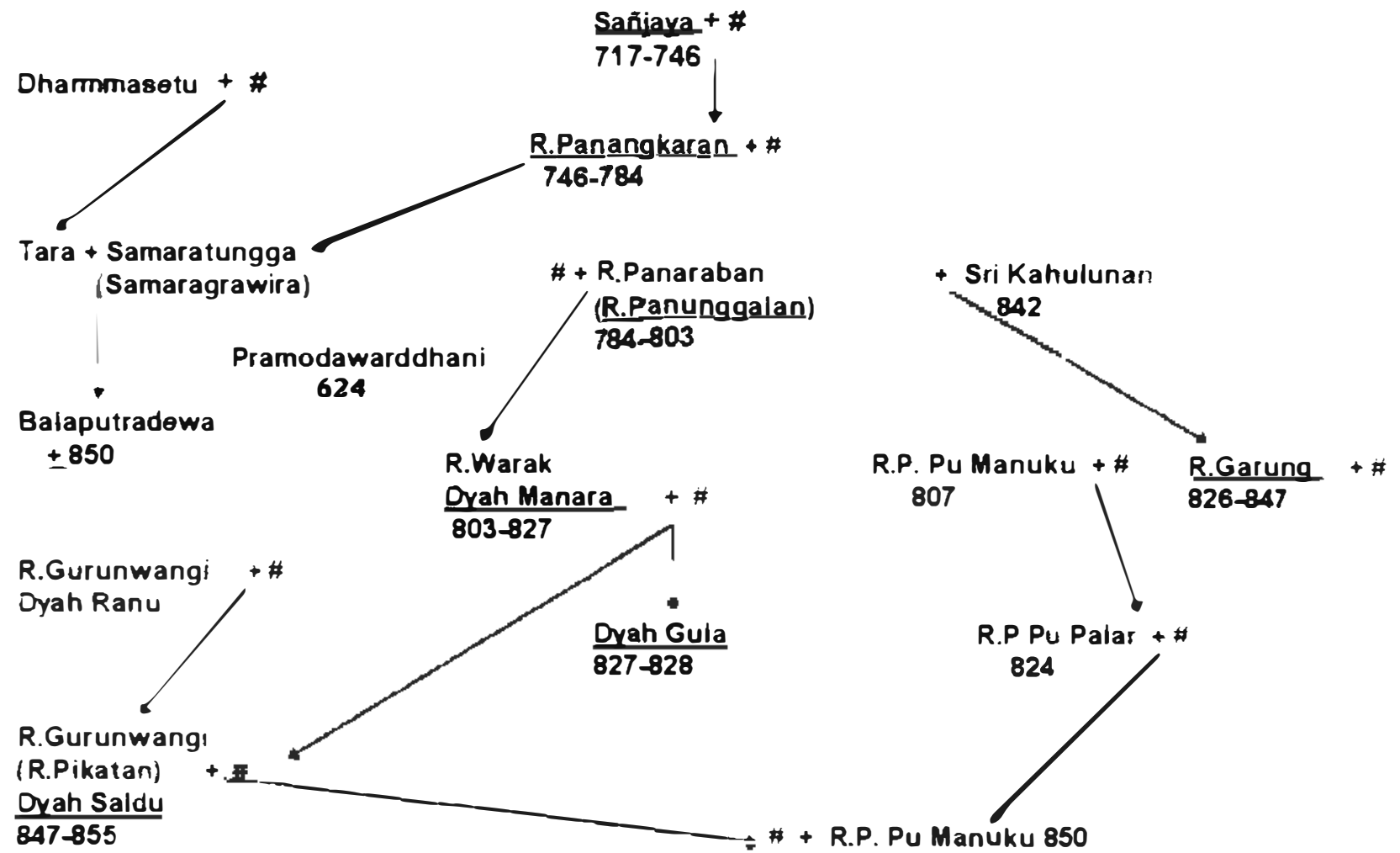

(R.Pikatan Pu Manuku) 863

\section{R.Kayuwangi Dyah Lokapala} 855-885

R. Panumwangan

Dyan Dewwndra + \# 885-887

(R.Limus Dyah Dewendral 890

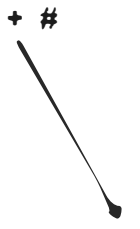

$\frac{\text { Dyah Tagwas }}{885}$
R.Gurunwangi Dyah Bhadra

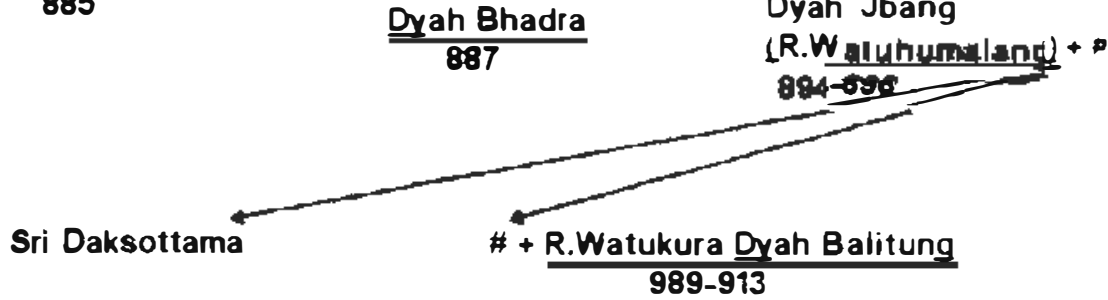

\section{Keterangan}

+ Kawin

\# Wanita menurunkan anak (dugaan cukup kuat)

menurunkan anak (dugaan kurang kuat) 